\title{
PARASITISM ON Eriosoma lanigerum (HOMOPTERA: APHIDIDAE) BY Aphelinus mali (HYMENOPTERA: ENCYRTIDAE) ON APPLE ORCHARDS, IN FRAIBURGO COUNTY, STATE OF SANTA CATARINA, BRAZIL ${ }^{1}$
}

\author{
LINO BITTENCOURT MONTEIRO², ALEXANDER SOUZA ${ }^{3}$, EDSON LUIZ BELLI ${ }^{4}$
}

\begin{abstract}
The parasitism of the woolly apple aphid (Eriosoma lanigerum Hausmann) by Aphelinus mali (Hald.) was evaluated in apple orchards cultivated with the varieties Gala and Fuji in Fraiburgo County, State of Santa Catarina, Southern Brazil. Colonies of the woolly apple aphid were evaluated during one year on 16 apple trees of each variety, starting in August 1999. The number of aphids at the mummy stage or presenting the orifice of the parasitoid emergence was recorded. Results have shown that A. mali parasitized more than 50\% of the woolly apple aphids and occurred during the four seasons. It was concluded that that under these conditions no chemical control against the aphid is necessary for the apple varieties Gala and Fuji.
\end{abstract}

Index terms: Biological control, parasitoid, woolly apple aphid.

\section{PARASITISMO DE Eriosoma lanigerum (HOMOPTERA: APHIDIDAE) POR Aphelinus mali (HYMENOPTERA: ENCYRTIDAE) EM POMARES DE MACIEIRA, EM FRAIBURGO, SC}

RESUMO - O parasitismo de pulgão lanígero por Aphelinus mali (Hald.) foi avaliado em pomares de macieira, contendo as variedades Gala e Fuji, em Fraiburgo, Santa Catarina. Foram avaliadas colônias de pulgão lanígero em 16 plantas de cada variedade, durante um ano, iniciando-se em agosto de 1999. Foi anotado o número de pulgões que se apresentavam no estágio de múmia ou apresentavam o orifício de emergência do parasitóide. Os resultados mostraram que $A$. mali parasitou mais de $50 \%$ dos pulgões lanígeros, nas quatro estações do ano. Concluiu-se que, nestas porcentagens de parasitismo, não é necessária nenhuma intervenção química para o controle do pulgão lanígero, em ambas as variedades.

Termo para indexação: Controle biológico, parasitóide, pulgão lanígero.

The woolly apple aphid Eriosoma lanigerum (Hausmann) (Homoptera: Aphididae) is a pest of the apple crop that can cause significant injuries to the plants (Bladley et al., 1997; Mols et al., 1999) since it feeds on the sap of new branches and sprouts. With the development of the woolly aphids on the apple trees, it groups into colonies presenting a white waxy filamentous covering. In the apple production region of Southern Brazil, as well as in other countries (Shaw et al., 1996; Nicholas et al. 1999) the chemical control of this pest is not satisfactory, since the layer of white waxy filaments protects the colony against contact insecticides. Consequently, systemic insecticides are recommended and vamidothion is one of the most used, despite its high toxicity to natural enemies such as Typhlodromus pyri Scheuten (Acari: Phytoseiidae) and micro-hymenopterans (Blaisinger, 1986; Association Nationale pour la Protection des Plantes, 1987; Bladley et al., 1997).

With the worldwide introduction of the parasitoid Aphelinus mali (Hald.) (Hymenoptera: Encyrtidae) from the USA, the biological control of E. lanigerum became feasible. In Brazil, where the introduction occurred in 1923 (Parra et al., 2002), the presence of $A$. mali on colonies of the aphid is easily observed, as well as mummified aphids or aphids with a dorsal orifice, which is characteristic of the micro-hymenopteran emergence. The parasitoid is susceptible to organophosphorous insecticides (Charmillot et al., 1997), however to protect the natural parasitism it is recommended the selective spray with vamidothion on the new sprouts of the apple rootstock in the spring or on the inferior third parts of the trees crown (Charmillot et al., 1997). This strategy would reduce the impact of the insecticide on the parasitoid A. mali, as well as on Neoseiulus californicus (McGregor) (Acari: Phytoseiidae), a predaceous mite used for the biological control of apple pests in Fraiburgo (Monteiro, 1993, 2001, 2002).

The objective of the present study was to quantify the natural parasitism of the woolly apple aphid by A. mali in commercial orchards in Fraiburgo, (State of Santa Catarina), Brazil.

The area of study was a 30 ha apple orchard belonging to the "Agrícola Fraiburgo" corporation, located in Fraiburgo, SC, divided in two 15 ha sub-plots each, cultivated with the varieties Gala and Fuji, both with $\mathrm{M} 7$ rootstock. In order to determine the A. mali parasitism index, 16 plants of each variety were randomly evaluated and the number of active woolly apple aphids, as well as the mummified ones black in color and those presenting an emergence orifice of the adult parasitoid in the dorsal side, was recorded. Between August 1999 and August 2000, eight surveys were carried out and during this period there was no specific chemical control against the woolly apple aphid.

Results have shown that $A$. mali parasitized the woolly apple aphid during all the sampling period on both apple varieties and the mean parasitism on Fuji and Gala were $63.7 \%$ and $61.2 \%$, respectively (Table 1). The numbers of woolly apple aphids sampled within the period remained stable, varying $20 \%$ around the mean, except in August 2000 for the variety Fuji with ca. $40.5 \%$ of parasitism, showing that in Fraiburgo the woolly apple aphid develops on the aerial parts of the apple trees during the four seasons. No winged populations of $E$. lanigerum were observed, probably because the winter is mild in that region, a different result from those obtained in regions of rigorous winters (Asante, 1999).

With these levels of parasitism, no symptoms of damage such as formation of galls or necrosis on the branches were observed, as it is characteristic of this species (Orth et al., 1986; Agnello et al., 1993). Thus, no chemical control was recommended within the sampling period. In other regions, even in the presence of $A$. mali, the use of insecticides to control the woolly apple aphid is necessary. Starting in the year 2000, the recommendation to apple producers in Fraiburgo is not to use insecticides against E. lanigerum before estimation of parasitism.

It was concluded that the natural parasitism of E. lanigerum by $A$. mali was higher than $50 \%$ and also that under these conditions no chemical control is necessary for the apple varieties Gala and Fuji.

\section{ACKNOWLEDGEMENTS}

The authors are thankful to the "Agrícola Fraiburgo" corporation for the financial support.

\footnotetext{
${ }^{1}$ (Trabalho 077/2004). Recebido: 24/06/2004. Aceito para publicção: 14/12/2004.

${ }^{2}$ Departamento de Fitotecnia e Fitossanitarismo, Universidade Federal do Paraná. Caixa postal 19.061, 81531-990, Curitiba, PR. E-mail: lbmonteiro@terra.com.br ${ }^{3}$ Eng. Agrônomo, Agrícola Fraiburgo S/A, Rod. SC 453, km 50, 89560-000, Videira, SC, Alex @ agricolafraiburgo.com.br

${ }^{4}$ Técnico Agrícola, Agrícola Fraiburgo S/A, Rod. SC 453, km 50, 89560-000, Videira, SC
} 
TABELA 1 - Natural parasitism on E. lanigerum by A. mali, in commercial apple orchard cultivated with the varieties Fuji and Gala, in Fraiburgo County, State of Santa Catarina, Southern Brazil, 1999-2000.

\begin{tabular}{|c|c|c|c|c|}
\hline \multirow{2}{*}{ Date } & \multicolumn{2}{|c|}{ Fuji } & \multicolumn{2}{|c|}{ Gala } \\
\hline & Total Aphid & Parasitism $(\%)$ & Total Aphid & Parasitism (\%) \\
\hline 19-08-99 & 747.0 & 75 & 690.0 & 71 \\
\hline $19-10-99$ & $1,007.0$ & 56 & $1,029.0$ & 57 \\
\hline $23-11-99$ & 756.0 & 74 & 690.0 & 71 \\
\hline $17-12-99$ & $1,048.0$ & 51 & 852.0 & 55 \\
\hline $30-05-00$ & $1,173.0$ & 86 & $\mathrm{x}$ & \\
\hline $08-08-00$ & $3,930.0$ & 41 & 730.0 & 74 \\
\hline Mean & & 63.7 & & 61.2 \\
\hline
\end{tabular}

\section{REFERENCES}

AGNELLO, A.; KOVACH, J.; NYROP, J.; REISSIG, H.; WILCOX, W.A guide for sampling and managing major apple pests in New York State. Ithaca: Cornell cooperative Extension, 1993, 68p.

ASANTE, S.K. Seasonal abundance of woolly apple aphid, Eriosoma lanigerum (Hausmann) and its important natural enemies in Armidale, Northern New South Wales. Plant-Protection Quarterly, Frankston, v.14, p.16-23, 1999.

ASSOCIATION NATIONALE POUR LAPROTECTION DES PLANTES. Les actions secondaires des produits phytosanitaires. Paris: Association Nationale pour la Protection des Plantes, 1987. 60p.

BLAISINGER P. Effet a court terme des produits phytosanitaires sur la faune auxiliaire. Essais successifs en verger de pruniers. IOBC/ WPRS Bulletin, Colmar, v. 9, p. 29-38, 1986.

BLADLEY, S.J.; MURRELL, V.C.; SHAW, P.W.; WALKER, J.T.S.; O’CALLAGHAN, M. Effect of orchard pesticides on Aphelinus mali, the woolly apple aphid parasitoid. Proceedings of the Fiftieth New Zealand Plant Protection Conference, 9., 1997, Canterbury.

CHARMILLOT, P.J.; BAILLOD, M.; BLOESCH, B.; LINDER, CH.; PASQUIER, D.; SCHAUB, L. Stratégies de lutrre contre les principaux ravageurs des arbres fruitiers. Revue suisse Viticulture, Arboriculture et Horticulture, Lausanne, n.29, p.39-44, 1997.

MOLS, P.J.M.; BOERS, J.M.; WAGENMAKERS, P.S.; WERF, W. VAN DER; BLAISE, P. A simulation study with a Dutch and a Canadian strain of the parasitoid Aphelinus mali (Hald.) for control of woolly apple aphid Eriosoma lanigerum (Hausmann) in the Netherlands. Acta-Horticulturae, Wageningen, v.499, p.261-268, 1999.

MONTEIRO, L. B. Controle biologique de Panonychus ulmi (Koch) (Acari: Tetranychidae) en fonction du programme de traitement contre la mouche des fruits dans la région de Vacaria (Brésil). In: CONFÉRENCEINTERNATIONALERAVAGERSENAGRICULTURE, 3, 1993, Montpellier, Anais... v. 2, p. 611-619.

MONTEIRO, L. B. Seletividade de inseticidas a Neoseiulus californicus McGregor (Acari: Phytoseiidae) em macieira, no Rio Grande do Sul. Revista Brasileira de Fruticultura, Jaboticabal, v.23, p.589-592, 2001. MONTEIRO, L. B. Manejo integrado de pragas em macieira no Rio Grande do Sul. II. Uso de Neoseiulus californicus McGregor (Acari: Phytoseiidae) para o controle de Panonychus ulmi Koch (Acari: Tetranychidae). Revista Brasileira de Fruticultura, Jaboticabal, v. 24, p.395-405, 2002.

NICHOLAS, A. H.; THWAITE, W.G.; SPOONER-HART, R.N. Arthropod abundance in an Australian apple orchard under mating disruption and supplementary insecticide treatments for codling moth, Cydia pomonella (L.) (Lepidoptera: Tortricidae). Australian Journal of Entomology, Melbourne, v.38, p.23-29, 1999.

ORTH, A. I.; RIBEIRO, L. G.; REIS FILHO, W. Manejo de pragas In: EMPASC, Manual da cultura da macieira. Florianópolis: EMPASC, 1986.562p.

PARRA, J. R.; BOTELHO, P. S.; CORRÊA-FERREIRE, B.; BENTO, J. M. S. Controle biológico: Terminologia. In: PARRA J.R.P., BOTELHO P.S.M., CORRÊA-FERREIRA B.S.; BENTO J.M.S. Eds. Controle biológico no Brasil: Parasitóides e predadores. São Paulo: Ed. Manole, 2002. p5-16.

SHAW, P.W.; WALKER, J.T.S.; O'-CALLAGHAN, M. Biological control of woolly apple aphid by Aphelinus mali in an integrated fruit production programme in Nelson. Proceedings of the Forty Ninth New Zealand Plant Protection Conference, v.6, p.59-63, 1996. 